\title{
Assessing the Impact of Service Quality on Customers and Operators: Empirical Study
}

\author{
Mohammad Sultan Ahmad Ansari ${ }^{1}$, Jamal Ahmad Farooquie ${ }^{2} \&$ Said Gattoufi $^{3}$ \\ ${ }^{1}$ Billing \& Settlement, Wholesale Business Unit, Sultanate of Oman \\ ${ }^{2}$ Department of Business Administration, Aligarh Muslim University, Aligarh, India \\ ${ }^{3}$ Institut Superieur de gestion de Tunis, Universite de Tunis, Tunisia \\ Correspondence: Mohammad Sultan Ahmad Ansari, Billing \& Settlement, Wholesale Business Unit, Omantel \\ Sultanate of Oman. E-mail: sultan_a_ansari@yahoo.com
}

Received: June 1, 2016

Accepted: July 6, 2016

Online Published: August 10, 2016

doi:10.5539/ijbm.v11n9p207

URL: http://dx.doi.org/10.5539/ijbm.v11n9p207

\begin{abstract}
The aim of this paper is to evaluate the impact of Service Quality on Customer Satisfaction, Customer Loyalty and Operational Performance of telecom service industry in Sultanate of Oman. It also investigate how technology adds value to service delivery system and improvement of Service Quality. The empirical data were collected by administering 1,450 questionnaires and out of which 888 completed and usable responses were retrieved. The study is first of kind that evaluated well-established chain of service i.e. services provided by Original Equipment Manufacturers to Telecom Service Providers and further service provided by the Telecom Service Providers to the End Users. The feedback was taken on forward and backward chain to evaluate comprehensive service chain, instead of evaluating an individual chain i.e. Service provided by Original Equipment Manufacturers to Telecom Service Providers or vice versa or from Telecom Service Providers to the End Users. Questionnaires feedback was taken from comprehensive chain of services, i.e. forward and backward chain feedback was considered. Research findings suggest that technological support would improve service delivery system and service organizations shall put special emphasize on Service Quality for achieving critical success, which would improve overall Customer Satisfaction, Customer Loyalty, Operational Performance and Firm Profitability.
\end{abstract}

Keywords: customer loyalty, customer satisfaction, operational performance, service quality, technology, telecom service industry

\section{Introduction}

Service Quality (SQ) significance is increasing service industry due to its prominence with customers and becoming major factor in customer's choice. Service companies started considering customer perception of SQ and how well it can be linked with services elements to meet customer's expectations. It enhances company business in the form of repeat purchase, customer retention, and "positive word of mouth". The SQ model originally identified ten elements, but later collapsed to five and those are Reliability, Assurance, Tangibles, Empathy and Responsiveness (RATER). It measures SQ in terms of customers' expectations and their perception of service received. According to Koduah and Farley (2016) managers seeking to improve Customer Satisfaction (CS) should focus their attention on assurance.

The empirical research by Evanschitzky, Sharma and Prykop (2012), Fazlzadeh, Faryabi, Darabi, \& Zahedi (2012), Lee (2013) established that SQ has positive impact on CS, Customer Loyalty (CL) and profitability of the service company. On the other hand researchers such as Kamakura, Mittal, Rosa, and Mazzon (2002), and Shekarchizadeh, Rasli, \& Tat, (2011) have not found any significance and reached to conclusions that higher SQ is not an unconditional guarantee of profitability. The SQ has become an ultimate source of achieving CS in service industry. It remains cross and multi-disciplinary issues of operations and strategic management. SQ and CS are indeed independent but they are closely related, implying that an increase in one is likely to surge other.

In this context there was a need to examine impact of technology on SQ and its bearing on CS, CL and Operational Performance (OP) in telecom service industry. Accordingly, the research framework was developed to address the objectives of the study, which has been empirically validated in telecom service industry in 
Sultanate of Oman. The telecom services included in this research are i.e. service facilitated from Original Equipment Manufacturers (OEMs) to Service Providers (SPs) and further service provided from SPs to the End Users (EUs) in telecom service industry in Oman.

Therefore the objectives of the study was set as follows:

1. To investigate contribution of technology in SQ

2. To investigate impact of SQ on CS, CL, and Firm Profitability (FP)

3. To assess FP and its influence in OP

4. To evaluate increased OP, further optimizes SQ.

The following section this research discusses literature review, research framework, hypotheses, methodologies, results and recommendations.

\section{Literature Review}

SQ is rapidly becoming a major factor in customer's choice for product or service. Industry shall ponder that how consumers are evaluating SQ and should aim to meet and exceed their expectation. In our day-to-day life we come across SQ in multiplicity of forms, from product advertising to service delivery. It further contributes in operational efficiency of the firm and an important aspect for business growth as consumer likes improved SQ.

According to Rasheed (2011) SQ and performance are associated through CS, which is always depends on how well service elements function together to meet customer's expectations in the competitive market. The challenges are designing of service and working out service delivery processes in line with the customer's expectations. The technology can be used as supporting device in service delivery system, which can assist in fulfilling customers' perception and eliminating uncertainties. It can play an important role in improving and elevating SQ. According to Abeysinghe and Paul (2005), technological capabilities changes customer focus, bring improvements in service, and improve overall efficiency. The influence of technology through which products and services are purchased and consumed by customers are becoming an important factor in service delivery system.

Technology savvy customers are forward looking, young, energetic and willing to accept challenges. They are likely to be satisfied and remain loyal while interacting with technologies rather than human interaction due to their innovative ideas and conformance to latest technology. These customers are possibly younger and often from affluent society. According to Gupta and Khanna (2015) technology-enabled delivery channels varies on age groups and annual income of customers.

The cost of quality is a major contributor, which accrue during service design and the cost further spill in delivery process. Finest design can prevent re-designing of service. The purpose of premium design is to keep customers satisfied, to get positive word of mouth, and create brand ambassadors. It enables managers to determine whether to spend on SQ or not, how much to be spend and evaluate its likely impact and contribution on service revenue and profitability. Technological assistances are likely to improve service delivery system and improve Customer Relationship Management (CRM).

\section{Research Framework and Research Questions}

The research model examines bearing of SQ on CS, CL, FP and OP of the firm. The SQ with the support of technology shall increase firm's OP in terms of revenue and profitability. The improved OP demands improved and optimized SQ to meet and exceed customer's expectation. Research model depicted in Figure-1 suggests that when SQ meets customer's expectations, CS, CL, FP increases that ultimately enhances OP, which further consolidate and improve SQ.

Technology, particularly the support of Information Technology (IT) plays a vital role service delivery system. Services offered by Amazon or eBay's are the examples of technological innovation. These services are shaped by buyers and sellers. The industry has benefitted from such service and service industries are further working on it for its further improvement. It assisted service industry to a large extent by minimizing direct human interaction with the customers.

Figure 1 shows the conceptual framework and based the theoretical background the following research questions are raised:

RQ1: Does the SQ added with technology having impact on CS and $C L$

RQ2: Does CS and CL affects FP. 
RQ3: Does increased FP increases $O P$.

RQ4: Does increased OP, attracts management attention to further optimize $S Q$ in order to meet and exceed customer's expectation.

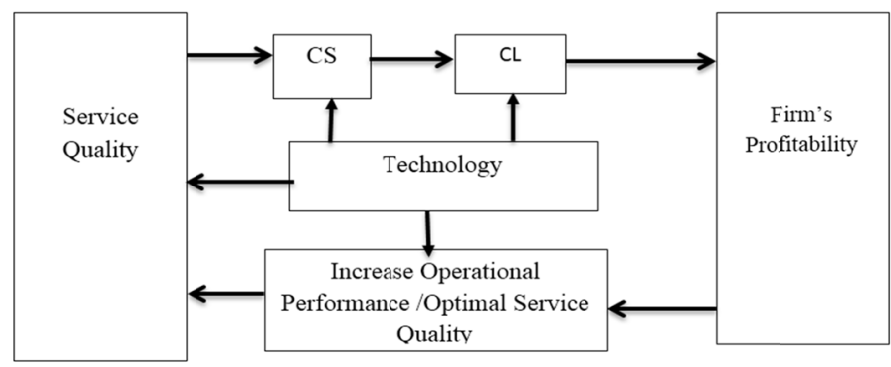

Figure 1. Conceptual framework

\section{Hypotheses Formulation}

The objectives of this study is to investigate the relationship between SQ and its bearing on CS and CL, FP and OP, which further consolidate and improve SQ in telecom service industry. The literature review shows a significant and positive relationship among these attributes and based on objectives of the study and literature review following hypotheses are formulated:

Service Quality, Customer Satisfaction and Customer Loyalty: The continuity of purchase from existing customer, positive word of mouth, encouraging potential buyers are the sign of CS and CL. According to Batayneh, A.Q., Ghaith M. Al-Abdallah., Hanadi A. Salhab., and Amer M. Shoter (2015) communication plays a positive and significant role in improving relationship quality, which ensures that both parties understand and share the information. The improved communication helps in adding values in service delivery system, increased revenue and profitability.

There is recurring cost involved in maintaining and improving SQ i.e. the cost incurred in training and skill development of service employees. However, it pay-back in terms of improved SQ, which ultimately increases EUs satisfaction and loyalty. There are possibility that the cost of quality may appears to be enormous in short term, whereas, in long run it derive immense value. It may initiate change management of service culture, organization aesthetic value, employee's behavior and influences customer's perception of SQ. The aesthetics and ambience can be used a unique tool to improve organizational culture, which can be achieved through internal and external customer's feedback from within and outside of company respectively.

The SQ depends upon the customer's perceived value, employee's initiatives, capability and wiliness to achieve best from available resources. Internal SQ does impact the employee's behavior, satisfaction and customer's satisfaction. According to Bellou and Andronikidis (2008) internal SQ positively and effectively increases SQ provided to the customers, which ultimately enhance customers' satisfaction. Hence, an improved SQ likely to impact on CS, CL, customer's retention, and eventually improve profitability. Accordingly, we posit that:

$\mathrm{HO}_{\mathrm{I}}$ : SQ added with technology has a positive and significant effect on CS.

$\mathrm{HO}_{2}$ : SQ has a positive and significant effect on $\mathrm{CL}$.

Customer Satisfaction and Customer Loyalty: The service companies seek continuous customer's feedback as part of customer relationship management. The service companies integrate those feedback in service delivery systems to win CS and CL. According to Low and Johnston (2006) the sense of loyalty and belongingness or affective commitment are to get closer to the buyers. Relationship and commitment create sense of belongingness, containment, improved customers' perceived values, satisfaction and loyalty. Researchers like Lai, Yeung, and Cheng (2012); Theoharakis, Sajtos, and Hooley (2009), found that CS increases CL and brand loyalty. In the competitive market, customers' satisfaction and loyalty is crucial in maintaining market leadership.

It is important for company to plan out the strategies for maintaining market leadership, since customers having options to choose services from competitors. Once, customer continue to opt services from existing service provider, which demonstrate that customers are contended, delighted. According to (Lariviere, Aksoy, \& Keiningham, 2011), customer satisfaction matters more when customers' adopts multiple channels and transact with multiple providers. Hence, high degree of customers' satisfaction and loyalty shall increase company's OP. 
However, managers need to make a balance between satisfaction and loyalty variables to a certain level. Beyond a certain point, it does not yields proportional return on investment or it might be getting diminishing return on investment. According to Jaiswal and Niraj (2011) the investments on satisfaction drivers provide diminishing returns in terms of customer's willingness to pay more. Therefore, service provider shall put certain efforts obtain highest level CS and CL and accordingly we propose that:

$\mathrm{HO}_{3}$ : CS positively and significantly influence $\mathrm{CL}$.

Customer Loyalty and sales from repurchase and referrals: The loyal customers purchase service, think instantly for next purchase and recommend their service provider to others. According to Williams and Naumann, (2011), there is clearly strong, positive and significant relationship between CS and willingness to recommend the company that increases firms' revenue. Increase in revenue is due to sharing of personal experience with other potential customers. Therefore, service provider should define business models that should give value for money to the customers. Service provider shall look beyond CS for accomplishment of current and future business thru increases sales, higher revenue and profitability.

The other areas of improvement for service provider is the Management Information System (MIS), and CRM. The improved MIS captures and secures customer's data that provide easiness to customers' and consolidate customers' confidence. Whereas, effective CRM improves system dynamics would likely to have leverage in finding current and future expected customers demand. MIS and CRM, together will improve system dynamics, enhance customers' repurchase intention and loyalty with existing brand.

The improved system dynamics can manage customer's data effectively that will assist in product bundling for different segments. It can assist in defining channel of distribution for increase value proposition. According to (Peppard 2000) integrated information is paramount for successful management of customer relationships. At the same time service companies need to suitably price and bundle the service for each segment. Price to be based on customer willingness to pay, market demand, corporate strategy, with an aim of achieving ultimately CS and loyalty. Accordingly we posit that:

$\mathrm{HO}_{4}$ : $\mathrm{CL}$ positively and significantly increases sales from repurchase and referrals.

Sales from Repurchase and referrals, profitability and its impact on SQ: According to Hallowell (1996) every customer satisfaction is related to profit. And every customer's satisfaction leads to repurchase. It can only happen when customers' are satisfied, loyal and willing to share their experiences to others. The positive word of mouth from contented and loyal customers will lead to increase in sales and strengthen market position. The CS can increase once the treated by loyal and satisfied employees supported with right technologies. According to Fazlzadeh et al. (2012) due to enhanced satisfaction, loyalty and capability of employees, customers' satisfaction and loyalty also grows.

Customers can experience differentiation when service is supported with technology. Since the technology facilitates prompt and effective action. It shall strengthen relationship that will lead to customers repurchase intentions. Every repurchase provides an opportunity to service provider to gather customer intelligence. The customer centric organization would utilize customer experience for gaining customer loyalty, positive word of mouth. It will lead to repurchase, eventually improve sales, increased revenue and profitability. The increase resale and profitability would force organization to further enhance SQ and OP for maintaining of its revenue and further enhancement. The relationship can only be developed with the satisfied and loyal customer who is willing to share their experience with the service provider.

The path to CL traverses through service value received by customers. It can be achieved by meeting and exceeding customer expectations. Once expectation are fulfilled, customer feels contended and likely to recommend service with the positive word of mouth. The increase OP shall optimize SQ for obtaining ultimate CS. Therefore, service provider shall think customer is always right, keeping in view that customer is a king. The customers shall be treated well for winning their loyalty, since customer can differentiate service from competitors and choose service provider. Accordingly we predict that:

$\mathrm{HO}_{5}$ : Sales from repurchase and referral significantly increase firm's profitability.

$\mathrm{HO}_{6}$ : Increase in firm's profitability significantly increases $\mathrm{OE}, \mathrm{SQ}$ with the help of technology.

\section{Research Methodology}

The purpose of any research is to accomplish objectives by following certain methodologies for validating the objectives of research. The research variables are generally industry specific, also depends upon objectives of the research and addressed segment. To accomplish the objectives of this research, a questionnaire survey 
methodology was adopted. The following section discusses research design, sampling methods, sample size, research questionnaires, pilot study and data collection method.

\subsection{Research Design}

This research used descriptive cum causal research designs. The convenience sample was used with an aim to approach 100 OEMs, 350 SPs and 1,000 EUs. Printed hard copy questionnaires was used for collection of data from OEMs, EUs and for SPs. Some intranet based questionnaires were circulated for SPs only with an aim to get top management feedback because direct contact with management was challenging.

\subsection{Sampling Frame}

The study was conducted in telecom service industry in the Sultanate of Oman. As one of researcher is working in this industry, which facilitated undoubtedly easy data collection. The data was collected from the complete chain of service delivery system, i.e. OEMs to SPs and from SPs to EUs. In this chain the OEMs were providing infrastructures and telecom services to SPs, whereas. SPs were responsible to facilitates services to EUs. Reasons for selecting OEMs, SPs and EUs was to evaluate the complete service chain, instead of evaluating an individual chain between OEMs to SPs or vice versa or SPs to EUs. Questionnaires feedback was taken on forward and backward chains with an intent to evaluate comprehensive chain of services.

\subsection{Sampling Method}

Sampling gathers required information from respective industry, segments through survey questionnaire. Researchers set objectives of the research by listing out the requisite information before designing of questionnaires. Researchers also decide the sample size in order to obtain an expected accuracy of the research. A good research design ensures that research projects are conducted effectively, efficiently, representing samples from all population segment. It is advisable to include samples from the entire county for obtaining uniform representation.

The EUs and SPs feedback was very important, hence, researcher decided to approach in person to OEMs and SPs for getting their feedback on questionnaire. Instead of deploying someone else would have not fetch similar result. Researchers achieved this task as sample sizes were smaller compare to the EUs.

\subsection{Sample Size}

The estimated total number of employees for all the OEMs having offices at the time of conducting survey were 600 and 4,400 for the SPs. whereas registered EUs with all SPs were 3.5 million. It was assumed that half a million EUs were having more than one services. Hence, individual EUs were approximately 3 million. Therefore, administered questionnaires were based on this assumption.

It was decided to avail $10 \%, 4 \%$ and $0.02 \%$ representations from OEMs, SPs and EUs that worked out of 60 (Yee, Yeung, and Cheng, 2011), 176 (Hadi, W., 2015) and 600 (Homburg, Wieseke and Hoyer, 2008) respectively. According to (Yee, Yeung, and Cheng, 2011) the sample size of 45 from agency service is considered adequate for the research. In this research the agency service considered as OEMs that providing equipment and services to the SPs. All the possible measures were taken to collect samples from all segments of society with uniform representations. Table 1 summarises target segments, sample size, questionnaire administered, retrieved questionnaire and response rate.

Table 1. Target segments, population, sample size, administered and retrieved questionnaire

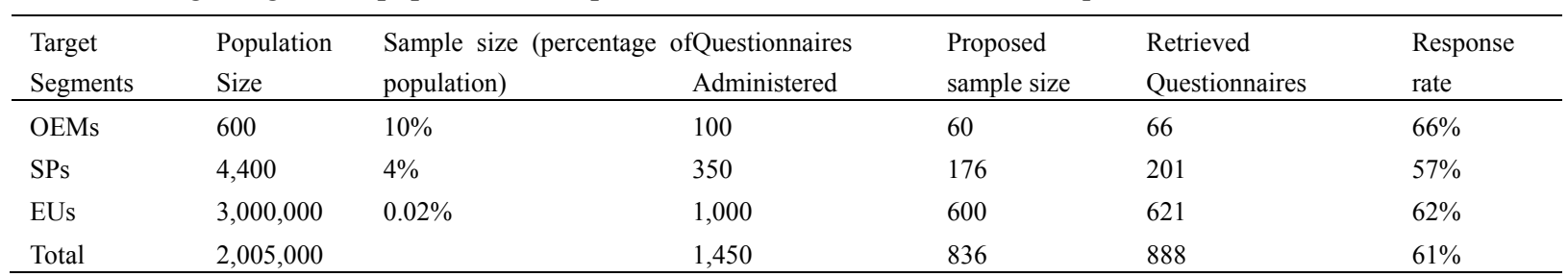

\subsection{Research Questionnaire and Data Collection}

A self-administered structured questionnaire was prepare containing three parts. The first part describing research topic, purpose of the research, researcher contact details and an assurance of confidentiality to respondent. The second part was comprising related questionnaires and the last and final part was respondent suggestions and word of thanks from researchers. Pilot study was conducted for all the three sets of 
questionnaires randomly selecting 5 employees each from OEMs and SPs and 10 EUs.

EUs and SPs questionnaire was circulated to top, middle level managers, supervisors and customer facing employees. Particularly, top management inputs were significant for all the traits of SPC and their feedback on SR and FP was noteworthy. Inputs from customer facing employees were equally important for evaluating traits like SQ, CS, CL and SR, as they being in position to observe unsaid customer's comments.

Researchers took friends, families and students' assistance for survey of EUs questionnaires with an aim to achieve uniform representation from all segments of society. As they belong to different parts of the country and visited their home during weekend, holidays. The feedback was uniformly distributed among all section of society, age group, profession, while maintaining male and female representation.

\section{Results}

Descriptive properties of all the domains, i.e. OEMs, SPs' and EUs were verified. Arithmetic means were examined to see how responses are centered; standard deviations to measure how responses are spread out and Cronbach's $\alpha(>0.6)$ to evaluate the criterion of reliability. The Cronbach's alpha value of all cases were found to be greater than 0.6 .

\subsection{Descriptive Properties of Variables for OEMs, SPs and EUs}

Table-2 represents descriptive properties of variables. The highest average responses are recorded for OEM's SQ $\left(\mathrm{SQ}_{\mathrm{M}}\right)$ followed by OEM's CS $\left(\mathrm{CS}_{\mathrm{M}}\right)$. The most consistent value was recorded for OEM's $\mathrm{CL}\left(\mathrm{CL}_{\mathrm{M}}\right)$. The standard deviation (SD) of $\mathrm{SQ}_{M}$ was recorded lower, which indicates that $\mathrm{SQ}_{M}$ will improve $\mathrm{CS}_{\mathrm{M}}$ and $\mathrm{CL}_{\mathrm{M}}$ that will improve financial performance of the firm.

Similarly, highest average responses were observed for SQ offered by SPs ( $\left.\mathrm{SQ}_{S}\right)$ to EUs and SP's firm profitability $\left(\mathrm{FP}_{\mathrm{S}}\right)$. The $\mathrm{SD}$ for Customer Loyalty of $\mathrm{SPs}\left(\mathrm{CL}_{\mathrm{S}}\right)$ and $\mathrm{SR}$ of $\mathrm{SP}$ 's $\left(\mathrm{SR}_{\mathrm{S}}\right)$ is 0.511 and 0.589 respectively that interpret $\mathrm{CL}_{\mathrm{s}}$ leads to $\mathrm{SR}_{\mathrm{s}}$.

Table 2. Descriptive properties for variables

\begin{tabular}{lllll}
\hline $\mathrm{SN}$ & Variables & Mean & Standard deviation & Cronbach's alpha \\
\hline 1 & $\mathrm{SQ}_{\mathrm{M}}$ & 3.84 & 0.569 & 0.82 \\
2 & $\mathrm{CS}_{\mathrm{M}}$ & 3.48 & 0.666 & 0.88 \\
3 & $\mathrm{CL}_{\mathrm{M}}$ & 3.42 & 0.567 & 0.85 \\
4 & $\mathrm{SR}_{\mathrm{M}}$ & 3.37 & 0.613 & 0.79 \\
5 & $\mathrm{FP}_{\mathrm{M}}$ & 3.43 & 0.698 & 0.91 \\
6 & $\mathrm{SQ}_{\mathrm{s}}$ & 3.41 & 0.674 & 0.74 \\
7 & $\mathrm{CS}_{\mathrm{s}}$ & 3.08 & 0.562 & 0.71 \\
8 & $\mathrm{CL}_{\mathrm{s}}$ & 3.35 & 0.511 & 0.75 \\
9 & $\mathrm{SR}_{\mathrm{s}}$ & 3.40 & 0.589 & 0.39 \\
10 & $\mathrm{FP}_{\mathrm{S}}$ & 3.52 & 0.627 & 0.79 \\
11 & $\mathrm{SQ}_{\mathrm{EU}}$ & 3.36 & 0.721 & 0.699 \\
12 & $\mathrm{CS}_{\mathrm{EU}}$ & 3.17 & 0.742 & 0.699 \\
13 & $\mathrm{CL}_{\mathrm{EU}}$ & 3.27 & 0.370 & 0.736 \\
14 & $\mathrm{SR}_{\mathrm{EU}}$ & 3.24 & 0.796 & 0.736 \\
\hline
\end{tabular}

Similarly EUs descriptive properties found to be highest average value for $\mathrm{SQ}_{\mathrm{EU}}$. The SQ to EUs are facilitated by SPs. The better $\mathrm{SQ}_{\mathrm{S}}$ will increase EU's $\mathrm{CL}\left(\mathrm{CL}_{\mathrm{EU}}\right)$ and $\mathrm{EU}$ willingness to repurchase $\left(\mathrm{SR}_{\mathrm{EU}}\right)$, which is recorded as 3.36, 3.27 and 3.24 respectively. It indicates that EUs loyalty leads to Sales from repurchase and referrals. These variables are highly interdependent and any deviation in one will impact others.

It can be interpreted that once EUs are satisfied with $\mathrm{SQ}_{\mathrm{s}}$; they will be loyal to their $\mathrm{SP}$ and do repurchase $\left(\mathrm{SR}_{\mathrm{EU}}\right)$. It is apparent that improved $\mathrm{SQ}_{\mathrm{EU}}$, shall fulfill customers' expectation, increase service productivity that will increase $\mathrm{CL}_{\mathrm{EU}}, \mathrm{SR}_{\mathrm{EU}}$ and ultimately enhance FP. According to Parasuraman (2002) companies delivering services must think more broadly about improving SQ and boosting service productivity.

\subsection{Combined Correlation Analysis of OEM, SP and End Users Variables}

To the best of our understanding this is the only study that tests complete chain of service delivery system. In 
most of the earlier study the researchers took feedback either from SPs and EUs or SPs only. In none of the studies OEMs' feedback were included. Following para discusses the combined correlation matrix of the selected variables.

All the samples of OEMs' was considered for combined correlation matrix. Whereas 66 samples were randomly selected from SPs and EUs. The purpose of randomly selecting sample was to make sure that all feedback from all the segments are included.

The Table 3 shows combined correlation results of selected variables in, which majority of the variables are positively and significantly correlated 0.01 levels (2-tailed). It conforms that there are inter-relationship exist among the selected variables. Variables like $\mathrm{SQ}_{\mathrm{M}}$ and $\mathrm{SRM}$ from OEMs, $\mathrm{SQ}_{\mathrm{S}}$ and $\mathrm{SR}_{\mathrm{S}}$ from $\mathrm{SPs}, \mathrm{CS}_{\mathrm{eu}}$ and $\mathrm{CL}_{\mathrm{eu}}$ from EUs were selected with an intention to find the linkage from the entire chain i.e. services rendered from OEMs' to SPs, and from SPs' to the EUs.

The respective variables were selected based on following assumptions:

- $\quad \mathrm{SQ}_{\mathrm{M}}$ and SPs to assess SQ offered by OEMs to SPs and from SPs to EUs.

- $\mathrm{SR}_{\mathrm{M}}$ and SPs to find SPs' repurchase intentions and their willingness to refer OEMs' services to others. Similarly SR from EUs' were considered to measure EUs intention of repurchase and their willingness to recommend services to others.

- $\quad \mathrm{CS}_{\mathrm{eu}}$ and $\mathrm{CL}_{\mathrm{eu}}$ to gauge EUs satisfaction and loyalty with their SP. It would generally lead to repurchase and willingness to recommend services to others that would lead to increase sales for SP's. An increase in sales will demand network expansion that will lead to OEMs sales and improved operational performance of SPs. According to (Yee, Yeung, \& Cheng, 2008), service quality and customer satisfaction eventually lead to financial gains.

Table 3. Combine correlation analysis of OEMs, SPs and EUs' variables

\begin{tabular}{llllllll}
\hline & & $\mathrm{SQ}_{\mathrm{M}}$ & $\mathrm{SR}_{\mathrm{M}}$ & $\mathrm{SQ}_{\mathrm{S}}$ & $\mathrm{SR}_{\mathrm{S}}$ & $\mathrm{CS}_{\mathrm{eu}}$ & $\mathrm{CL}_{\mathrm{eu}}$ \\
\hline $\mathrm{SQ}_{\mathrm{M}}$ & Pearson Correlation & 1 & $0.382^{* *}$ & 0.115 & 0.125 & 0.156 & 0.066 \\
& $\mathrm{Sig}$ (2-tailed) & & 0.002 & 0.357 & 0.316 & 0.211 & 0.599 \\
& $\mathrm{~N}$ & 66 & 66 & 66 & 66 & 66 & 66 \\
$\mathrm{SR}_{\mathrm{M}}$ & Pearson Correlation & & 1 & 0.109 & 0.063 & 0.135 & 0.012 \\
& $\mathrm{Sig}$ (2-tailed) & & & 0.385 & 0.614 & 0.279 & 0.922 \\
& $\mathrm{~N}$ & & 66 & 66 & 66 & 66 & 66 \\
$\mathrm{SQ}$ & Pearson Correlation & & & 1 & $0.644^{* *}$ & $0.674^{* *}$ & $0.620^{* *}$ \\
& $\mathrm{Sig}$ (2-tailed) & & & & 0.000 & 0.000 & 0.000 \\
& $\mathrm{~N}$ & & & 66 & 66 & 66 & 66 \\
$\mathrm{SR}$ & Pearson Correlation & & & & 1 & $0.680^{* *}$ & $0.799^{* *}$ \\
& $\mathrm{Sig}$ (2-tailed) & & & & & 0.000 & 0.000 \\
& $\mathrm{~N}$ & & & & 66 & 66 & 66 \\
$\mathrm{CS}_{\mathrm{EU}}$ & Pearson Correlation & & & & 1 & $0.724^{* *}$ \\
& $\mathrm{Sig}$ (2-tailed) & & & & & & 0.000 \\
& $\mathrm{~N}$ & & & & & 66 & 66 \\
$\mathrm{CL}_{\mathrm{EU}}$ & & & & & & 1 \\
& & & & & & 66 \\
\hline
\end{tabular}

The combined correlation coefficient for $\mathrm{CL}_{\mathrm{EU}}$ and $\mathrm{SR}_{\mathrm{S}}=0.799$ that interpret that due to EUs loyalty with SPs, which will increase sales due to repeat purchase and positive word of mouth. The other strong correlations were found between $\mathrm{CS}_{\mathrm{EU}}$ and $\mathrm{CL}_{\mathrm{EU}}, \mathrm{SQ}_{\mathrm{S}}$ and $\mathrm{SR}_{\mathrm{S}}, \mathrm{CS}_{\mathrm{EU}}$ and $\mathrm{SR}_{\mathrm{S}}$ that construes:

- $\quad \mathrm{CS}_{\mathrm{EU}}$ will increase $\mathrm{CL}_{\mathrm{EU}}$

- $\quad \mathrm{SQ}_{\mathrm{S}}$ will increase $\mathrm{SR}_{\mathrm{S}}$

- $\quad \mathrm{CS}_{\mathrm{EU}}$ will increase $\mathrm{SR}_{\mathrm{S}}$

All these relationships show SQ, CS, CL and SR are interrelated to each other, which is in line with assumptions and Heskett et al (1994) postulates that highly satisfied customers drive growth and profitability in service businesses. SQ, CS and CL can be further improved by deploying right technology, since EUs demands are 
dynamic, which is changing with technological advancement. Similar finding drawn by Evanschitzky et al (2012), which indicated that customer's evaluation of SQ, product quality and value derived depend upon CS.

The combined correlation matrixes show that all the variables are significantly correlated and cohesive relationships were observed between $\mathrm{CS}_{\mathrm{EU}}$ and $\mathrm{CL}_{\mathrm{EU}}, \mathrm{SQ}_{\mathrm{S}}$ and $\mathrm{SR}_{\mathrm{S}}, \mathrm{CS}_{\mathrm{EU}}$ and $\mathrm{SR}_{\mathrm{S}}, \mathrm{CL}_{\mathrm{EU}}$ and $\mathrm{SR}_{\mathrm{S}}$, which is in line with assumptions.

\subsection{Comparing Regression Results (R2 and ANOVA) of the Three Tiers'}

Table 4 represents three tier Regression analysis of research hypotheses that scrutinizes the relationship between single and multiple dependent variables. The values of $\mathrm{R}^{2}$ for entire variables were found to be positive and significant. Hence, it worth discussing those variables having high values of $\mathrm{R}^{2}$ such as:

- $\quad \mathrm{CL} \& \mathrm{SR}=0.510$, and $\mathrm{SR}$ and $\mathrm{FP}=0.642$ of $\mathrm{OEM}$ s' variables $^{\prime}$

- $\quad \mathrm{CL} \& \mathrm{SR}=0.542$ of SPs' variables

- $\quad \mathrm{CS} \& \mathrm{CL}=0.477$, and $\mathrm{CL} \& \mathrm{SR}=0.530$, EUs variables

Table 4. Comparing regression results ( $\mathrm{R}^{2}$ and ANOVA) of three tiers

\begin{tabular}{|c|c|c|c|c|}
\hline Variables & $\mathrm{R}^{2}$ and ANOVA & OEMs & SPs & End users \\
\hline \multirow{3}{*}{ CS-CL } & $\mathrm{R}^{2}$ & 0.418 & 0.443 & NA \\
\hline & $\mathrm{F}$ & 6.784 & 12.338 & NA \\
\hline & Sig & 0.000 & 0.000 & NA \\
\hline \multirow{3}{*}{ CL-SR } & $\mathrm{R}^{2}$ & 0.510 & 0.542 & NA \\
\hline & $\mathrm{F}$ & 8.167 & 15.361 & NA \\
\hline & Sig & 0.000 & 0.000 & NA \\
\hline \multirow{3}{*}{ SR-FP } & $\mathrm{R}^{2}$ & 0.642 & 0.284 & NA \\
\hline & $\mathrm{F}$ & 6.701 & 8.887 & $\mathrm{Na}$ \\
\hline & Sig & 0.000 & 0.000 & NA \\
\hline \multirow{3}{*}{ SQ-CS } & $\mathrm{R}^{2}$ & NA & NA & 0.366 \\
\hline & $\mathrm{F}$ & NA & NA & 18.904 \\
\hline & Sig & NA & NA & 0.000 \\
\hline \multirow{3}{*}{ CS-CL } & $\mathrm{R}^{2}$ & NA & NA & 0.477 \\
\hline & $\mathrm{F}$ & NA & NA & 23.742 \\
\hline & Sig & NA & NA & 0.000 \\
\hline \multirow{3}{*}{ CL-SR } & $\mathrm{R}^{2}$ & NA & NA & 0.530 \\
\hline & $\mathrm{F}$ & NA & NA & 26.433 \\
\hline & Sig & NA & NA & 0.000 \\
\hline
\end{tabular}

The highest value of $\mathrm{R}^{2}$ was derived of SR and $\mathrm{FP}=0.642$ for OEMs. The reason for extraordinary profitability for OEMs' might be due the fact that SPs' compulsion to continue with the existing OEM due to network specifications, compatibility operability etc. OEMs might provide initial equipment at lower cost to get the footage and negotiate strongly for future expansion. According to Agrell et al (2004), previously integrated firms hold bargaining power in the competitive market. Similarly high value of $\mathrm{R}^{2}=0.510$ was establish for $\mathrm{CL}$ and $\mathrm{SR}$ of OEMs'. It might be due to SPs loyalty with OEM and lack of available options with SPs.

Other high value of $\mathrm{R}^{2}=0.542$ was found for CL and SR for SPs', which is obvious that loyal customers will continue to repurchase and recommend the service. Hence, SPs should develop strategy for customers' retention by signing long term contract. There could be many ways to retain customers, such as, by rewarding loyalty points on every repurchase, on usages, sharing profit on purchase of mobile phones. The $\mathrm{R}^{2}$ value of CL-SR is 0.53 , which interprets that loyal customers put positive word of mouth and share encouraging experience to others. The other high value of $\mathrm{R}^{2}$ were for CS- CL related to EUs', which is noticeable that EUs satisfaction would lead to loyalty that consciously or unconsciously create promoter and brand ambassador for SPs.

Researchers like Armistead and Kiely, (2003); Gelade and Young, (2005); Homburg (2009); Yee, Yeung, and Cheng, (2011); Williams and Naumann, (2011); Evanschitzky et al. (2012); Kanyurhi (2013) tested S-PC's links in different industries, at different locations and found close association among SPC's variables. Therefore, based on results and comparison of regression results ( $\mathrm{R}^{2}$ and ANOVA) of three tiers, it is found that the values of $\mathrm{R}^{2}$ for the entire variables are positive and significant, which shows that the results are in line with assumptions. 
According to Hadi (2015) Telecom organizations may need to follow a combined strategy aimed at managing customer attraction to improve competitive advantage. Hence, it is presumed that SQ associated with right technology would improve CS, CL and OP that would optimize SQ of telecom services. The support of modern technologies is vital for achieving such performance. According to Bitner Mary Jo (2010) technologies and service innovations resulting in better understanding of the gaps and closing of gaps.

\section{Discussion}

The overall objectives of the study was to examine contribution of technology on SQ, CS, CL OP and FP telecomm service industry. The analysis covered complete chain of service delivered from OEMs' to SPs and from SPs' to the EUs. Based on assumptions the framework was developed to address its objectives. The data was collected from OEMs, SPs and EUs by using questionnaires. The questionnaires for OEMs' and SPs' addressed the attributes like SQ, CS, CL, SR and FP. The EUs' questionnaires was restricted to SQ, CS, CL, and SR since other attributes were not applicable for it.

The study was empirically validated in the proposed model, which is unique and to best of our understanding none of the study have been empirically tested in telecom service industry. This study was first to adapt and it was empirically validated in a well-established complete chain of services.

\section{Conclusion}

Service organizations shall put special emphasize on SQ for achieving critical success, which would improve overall CS and CL. The improved CS and CL would have positive impact on SR, OP and FP. The research model proposed that technology would help in improving service delivery system. It will increasing productivity, add value in SQ, CS, CL and OP of the company. Increase efficiency would collaborate in further optimizing SQ.

The research findings can be applied in real-world for achieving ultimate success in the service organization. It would more value in terms of SQ, CS, and CL when service industries are supported with modern technologies. Attributes like SQ, CS, and CL are dynamic and shall be continuously monitored by service managers. In the fast changing environment, managers shall continuously monitor market situation and to make sure SQ is maintained and optimized with the time and corrective actions should be initiated in case of adverse report of SQ. Technological support would certainly improve service delivery system and it would improvement, optimize service delivery system.

Findings of this study provide valuable knowledge in services sectors in general and telecom sectors in particular. It shall benefit service professionals, academicians, consultants, strategic planners and quality practitioners who would like to improve overall operational efficiency.

Finally, this is the most significant academic contribution for telecom industry in the Sultanate of Oman and all hypotheses test results are found in line with assumptions. Similar study can be considered in other service sectors such as petroleum, oil and gas, construction or consultancy sectors by validating its attributes using structure equation modeling tools.

\section{Acknowledgements}

The researchers are thankful to the Sultanate of Oman, where research was accomplished. Researchers are also thankful to OEMs, SPs, EUs, friends, family and students for their contribution and untiring efforts for collection of data from different sources.

\section{References}

Abeysinghe, D., \& Paul, H. (2005). Privatization and technological capabilities development in telecommunications sector: A case study of Sri Lanka telecom. Technology in Society, 27, 487-516. http://dx.doi.org/10.1016/j.techsoc.2005.08.010

Agrell. P. J., Lindroth, R., \& Norrman, A. (2004). Risk Information and Incentives in Telecom Supply Chains. International Journal of Production Economics, 1-16. http://dx.doi.org/10.1016/S0925-5273(02)00471-1

Alshareef1, M. N. Z., \& Sandhu, K. (2015). Integrating Corporate Social Responsibility (CSR) into Corporate Governance Structure: The Effect of Board Diversity and Roles-A Case Study of Saudi Arabia. International Journal of Business and Management, 10(7). 1-15. http://dx.doi.org/10.5539/ijbm.v10n7p1

Armistead, C., \& Kiely, J. (2003). Creating strategies for managing evolving customer service. Managing Service Quality, 13(2), 164-170. http://dx.doi.org/10.1.1108/09604520310466860

Bataineh, A. Q., Ghaith, M., Al-Abdallah, H., Salhab, A., \& Amer, M. S. (2015). The Effect of Relationship Marketing on Customer Retention in the Jordanian's Pharmaceutical Sector. International Journal of 
Business and Management, 10(3), 117-131. http://dx.doi.org/10.5539/ijbm.v10n3p117

Bellou, V., \& Andronikidis, A. (2008). Impact of Internal Service Quality on customer service behavior: Evidence from banking sector. International Journal of Quality \& Reliability Management, 25(9), 943-954. http://dx.doi.org/10.1108/02656710810908098

Bhuiyan, F., Rahman, M. M., \& Gani, M. O. (2015). Impact of Human Resource Information Systems on Firms' Financial Performance. International Journal of Business and Management, 10(10), 171-185. http://dx.doi.org/10.5539/ijbm.v10n10p171

Bitner, M. J. (2010). Technology's Impact on the Gaps Model of Service Quality, Handbook of Service Science. Service Science, 197-218. http://dx.doi.org/10.1007/978-1-4419-1628-0_10

Evanschitzky, H., Sharma, A., \& Prykop, C. (2012). The role of the sales employee in securing customer satisfaction. $\quad$ European Journal of Marketing, 469-508. http://dx.doi.org/10.1108/03090561211202576

Evanschitzky, H., Wangenheim, F. V., \& Wunderlinch, N. V. (2012). Perils of Managing the Service Profit Chain: The Role of Time Lags and Feedback Loops. Journal of Retailing, 88(3), 356-366. http://dx.doi.org/10.1016/j.jretai.2012.01.003

Fazlzadeh, A., Faryabi, M., Darabi, H. A., \& Zahedi, B. (2012). A Survey on the Effect of Service Delivery System on Corporate Performance Using Service Profit Chain Model. International Journal of Business and Management, 7(6), 161-171. http://dx.doi.org/10.5539/ijbm.v7n6p161

Gelade, G. A., \& Young, S. (2005). Test of service profit chain model in the retail banking sector. Journal of Occupational and Organizational Psychology, 78, 1-22. http://dx.doi.org/10.1348/096317904X22926

Grissemann, U. S., \& Stokburger-Sauer, N. E. (2012). Customer co-creation of travel services: The role of company support and customer satisfaction with the co-creation performance. Tourism Management, 33, 1483-1492. http://dx.doi.org/10.1016/j.tourman.2012.02.002

Gupta, N., \& Khanna, V. T. (2015). Customer's Adoption for Technology-Enabled Delivery Channels in Selected Public Sector Banks. International Journal of Business and Management, 10(12), 215-225. http://dx.doi.org/10.5539/ijbm.v10n12p215

Hadi, W. (2015). The Relationship between CRM Strategies Stage on Competitive Advantage: An Analytical Perspective. International Journal of Business and Management, 10(8), 245-251. http://dx.doi.org/10.5539/ijbm.v10n8p245

Hallowell, R. (1996). The relationship of customer satisfaction, customer loyalty, and profitability: An empirical study. International Journal of Service Industry Management, 7(4), 27-42. http://dx.doi.org/10.1108/09564239610129931

Heskett, J. I., Jones, T. O., Loveman, G. W., Sasser, W. E., \& Schlesinger, L. A. (1994). Putting the Service Profit Chain to Work. Best of Harvard Business Review (HBR), 164-170. https://hbr.org/2008/07/putting-the-service-profit-chain-to-work

Homburg, C., Wieseke, J., \& Hoyer, W. D. (2009). Social Identity and Service Profit Chain. Journal of Marketing Article Post-Print, American Marketing Association, 1-44. http://dx.doi.org/10.1509/jmkg.73.2.38

Isaac, B. (2015). Profitability Determinants of the Ghanaian Banking Sector in Ongoing Wave of Consolidation. International Journal of Business and Management, 10(12), 1-11. http://dx.doi.org/10.5539/ijbm.v10n12p1

Jaiswal, A. K., \& Niraj, R. (2011). Examining mediating role of attitudinal loyalty and nonlinear effects in satisfaction-behavioral intentions relationship. Journal of Service Marketing, 25(3), 165-175. http://dx.doi.org/10.1108/08876041111129155

Kamakura, W. A., Mittal, V., Rosa, F. D., \& Mazzon, J. A. (2002). Assessing the Service-Profit Chain. Marketing Science, 21(3), 294-317. http://dx.doi.org/10.1287/mksc.21.3.294.140

Kanyurhi. E. B. (2013). Evaluation of customer satisfaction with services of a micro-finance institution: Empirical evidence from Women Association for Social and Economic Gain customers' in Togo. African Journal of Marketing Management, 5(2), 26-37. http://dx.doi.org/10.5897/AJMM11.128

Koduah, E. Y. T., \& Farley, A. Y. D. (2016). Relationship between Customer Satisfaction and Customer Loyalty in the Retail Banking Sector of Ghana. International Journal of Business and Management, 11(1), 249-262. 
http://dx.doi.org/10.5539/ijbm.v11n1p249

Lai, K. H., Yeung, A. C. L., \& Cheng, T. C. E. (2012). Configuring quality management and marketing implementation and the performance implications for industrial marketers. Industrial Marketing Management. http://dx.doi.org/10.1016/j.indmarman.2012.07.003

Lariviere, B., Aksoy, L., Cooil, B., \& Keiningham, T. L. (2011). Does satisfaction matter more if a multichannel customer is also a multi-company customer. Journal of Service Management, 22(1), 39-66. http://dx.doi.org/10.1108/09564231111106910

Lee, H. S. (2013). Major Moderators Influencing the Relationships of Service Quality, Customer Satisfaction and Customer Loyalty. Asian Social Science, 9(2). http://dx.doi.org/10.5539/ass.v9n2p1

Low, B., \& Johnston, W. J. (2006). Relationship equity and switching behavior in the adaption of new telecommunication services. Industrial Marketing Management, 35, 676-689. http://dx.doi.org/10.1016/j.indmarman.2005.05.007

Mittal, S., \& Mittal, V. (2015). Employee Commitment in Public and Private Banks in India. International Journal of Business and Management, 10(11), 199-2015. http://dx.doi.org/10.5539/ijbm.v10n11p199

Parasuraman, A. (2002). Guru's view-Service Quality and productivity: A synergistic perspective. Managing Service Quality, 12(1). http://dx.doi.org/10.1108/09604520210415344

Parasuraman, A., \& Grewal, D. (2000). The impact of Technology on the Quality-Value-Loyalty Chain: A research agenda. Academy of Marketing Science Journal, 168-174. http://dx.doi.org/10.1177/0092070300281015

Peppard, J. (2000). Customer Relationship Management (CRM) in Financial Services. European Management Journal, 18(3), 312-327. http://dx.doi.org/10.1016/S0263-2373(00)00013-X

Rasheed, M. (2011). Does Technology-Enabled Service Quality affect Organizational Competencies? Journal of Public Administration and Governance, 1(2). http://dx.doi.org/10.5296/jpag.v1i2.791

Shekarchizadeh, A., Rasli, A., \& Tat, H. H. (2011). SERVQUAL in Malaysian universities: Perspectives of international students. Business Process Management Journal, 17(1), 67-81. http://dx.doi.org/10.1108/14637151111105580

Theoharakis, V., Sajtos, L., \& Hooley, G. (2009). The strategic role of relational capabilities in the business-to-business service profit chain. Industrial Marketing Management, 38, 914-924. http://dx.doi.org/10.1016/j.indmarman.2009.04.006

Tracey, M. R., Marion, T. M., \& Onu, S. (2015). Insights from Global Project Managers: Career Advice for Successful International Assignments. International Journal of Business and Management, 10(10), 9-18. http://dx.doi.org/10.5539/ijbm.v10n10p9

Wang, X., \& Meng, T. (2016). The Research of Customers Satisfaction and Public Policy \& Marketing Design in Special Interest Tourism-Macao Culinary Tourism. International Journal of Business and Management, 11(1), 124-135. http://dx.doi.org/10.5539/ijbm.v11n1p124

Williams, P., \& Naumann, E. (2011). Customer satisfaction and business performance: A firm-level analysis. Journal of Service Marketing, 25(1), 20-32. http://dx.doi.org/10.1108/08876041111107032

Yee, R. W. Y., Yeung, A. C. L., \& Cheng, C. E. C. (2008). The impact of employee satisfaction on quality and profitability in high-contact service industries. Journal of Operations Management, 26, 651-668. http://dx.doi.org/10.1016/j.jom.2008.01.001

Yee, R. W. Y., Yeung, A. C. L., \& Cheng, C. E. C. (2011). An empirical Analysis in high contact service industries. International Journal of Production Economics, 130, 236-245. http://dx.doi.org/10.1016/j.ijpe.2011.01.001

\section{Copyrights}

Copyright for this article is retained by the author(s), with first publication rights granted to the journal.

This is an open-access article distributed under the terms and conditions of the Creative Commons Attribution license (http://creativecommons.org/licenses/by/4.0/). 